\title{
Effect of hot and cold treatments for the management of Pulse beetle Callosobruchus maculatus (Fab) in pulses
}

\author{
J.Alice R.P.Sujeetha ${ }^{1}$ and N.Srikanth ${ }^{2}$ \\ 1Department of Food Microbiology,Indian Institute of Crop ProcessingTechnology,Thanjavur, 613 005,Tamil \\ Nadu,India \\ 2Department of Entomology,Pandit Jawaharlal Nehru College of Agriculture \& Research Institute,Karaikal, \\ Puducherry, 609603 -India
}

\begin{abstract}
The pulse beetle C. maculatus (Fab.) is a major pest of economically important leguminous grains, such as cow peas, lentils, green gram, and black gram. Effect of sun drying on oviposition of pulse beetle, $C$. maculatus showed 100 per cent egg mortality during the second, third and fourth months. It was observed that there is no significant difference among the exposure periods. Effect of sun drying on adult emergence of pulse beetle, C. maculatus, indicated that 100 per cent adult mortality was recorded during the second, third and fourth months and significant difference was not observed among the exposure periods. Effect of cold treatment on oviposition of the pulse beetle, C. maculatus recorded with 100 per cent mortality and no significant difference was noticed among the exposure periods in which was observed. Effect of cold treatment on adult emergence of the pulse beetle, C. maculatus revealed 100 per cent adult mortality was observed in all the exposure period during the second, third and fourth months.
\end{abstract}

Key words: Adult beetles, Bruchids,Black Gram,Cold treatment, Oviposition,Sun drying

\section{Introduction}

Pulses, also called grain legumes, which are extensively grown in tropical regions of the world for centuries as a major protein rich crop bringing considerable improvement in human diet [1] .India is one of the major pulse growing countries in the world with a total area of 23.31 million hectares and a total production of 14.50 million tonnes[2] . .Among the different pulses, black gram is a rich source of protein which is one of the essential nutrients of human diet. Black gram (Vigna mungo L.) contributes 10 per cent to the national pulse production from an area of 13 per cent. This crop is grown in 3 million hectares area producing 1.37 million tonnes of grains. It is grown in part of Asia and South Africa. In India it is mostly cultivated in Madhya Pradesh, Maharashtra, Andhra Pradesh, Uttar Pradesh, Karnataka, Tamil Nadu and West Bengal.

Pulses are rich sources of protein as they contain about 20-30 per cent protein, which is almost three times higher than that found in cereals but these are more difficult to store than cereals as they suffer great damage during storage due to insect-pests and microorganisms[3]. Insect pests have been a threat to food and seed since man has started growing crops. Almost all stored food stuffs and seeds are liable to insect injury[4] . Among the insect-pests, bruchids are well known to inflict post-harvest loss to stored legumes, primarily through consumption of the resource, and secondarily through the qualitative deterioration of the commodity or reduced seed stock viability[5]They are the important pests of pulse crops in Asia and Africa under storage conditions $[6,7,8]$.

The pulse beetle $C$. maculatus is a major pest of economically important leguminous grains, such as cow pea, lentil, green gram, and black gram $[910,11]$. During storage, black gram is damaged to a great extent by pulse beetle, $C$. maculatus. The pest being an internal feeder lay eggs on the seed surface in the field as well as during threshing which hatch during storage. As and when the congenial conditions become available and the insect multiplies. The infested seeds are unfit for planting or for human consumption[12] .

In order to preserve the seed material several measures have been employed from time to time. To manage this storage pest, different strategies are tried by the scientists. But still it continued to be a threatening pest in storage. The use of pesticides has been employed by the farmers. Though this pesticides have positive effect on the pests, they continued to remain hazardous to man and the environment. With the objective of providing quality food for general public the interest of this research have been directed towards finding alternative to pesticide that are environmentally friendly and does not pose dangers to man.

\section{Materials And Methods}

\subsection{Effect of sun drying on pulse beetle, Callosobruchus maculatus (Fab.)}

The experiment was set up to study the management of pulse beetle through solar energy in stored black gram seeds. Six treatments were maintained and the experiment was replicated thrice. Ten pairs of newly 
emerged adults were released in each replication and allowed the adults to lay eggs for 3 days after which the adults were removed from all the treatments. All the treatments were exposed to sun light, bimonthly at the maximum of $4 \mathrm{~h} /$ day from $8 \mathrm{AM}$ to $12 \mathrm{PM}$, i.e. $4 \mathrm{~h}$ ( $1^{\text {st }}$ day $), 8 \mathrm{~h}\left(1^{\mathrm{st}}\right.$ and $2^{\text {nd }}$ day $), 12 \mathrm{~h}\left(1^{\text {st }}, 2^{\text {nd }}\right.$ and $3^{\text {rd }}$ day $), 16 \mathrm{~h}$ $\left(1^{\text {st }}, 2^{\text {nd }}, 3^{\text {rd }}\right.$, and $4^{\text {th }}$ day), $20 \mathrm{~h}\left(1^{\text {st }}, 2^{\text {nd }}, 3^{\text {rd }}, 4^{\text {th }}\right.$ and 5 th day $)$ and $24 \mathrm{~h}\left(1^{\text {st }}, 2^{\text {nd }}, 3^{\text {rd }}, 4^{\text {th }}, 5^{\text {th }}\right.$ and $6^{\text {th }}$ day $)$. Similarly all the treatments were exposed to refrigerated condition $\left(4^{\circ} \mathrm{C}\right)$ bimonthly for $4,8,12,16,20$ and $24 \mathrm{~h}$. The number of eggs and adult insect were recorded every month and the observations were continued till four months.

\subsection{Effect of cold treatment on pulse beetle, Callosobruchus maculatus (Fab.)}

One hundred grams of disinfested seeds were taken in plastic container and ten pairs of newly emerged uniform aged adults were released for egg laying. Adults were removed after 3 days of egg laying and number of eggs were counted. Seeds with three day aged eggs were kept in plastic containers and each treatment was replicated thrice and was exposed to cold temperature regimes for different exposure periods $\quad(4,8,12,16,20$ and 24h) and a control was maintained at room temperature. Later the seeds along with eggs were taken out and kept at ambient condition $\left(27 \pm 2{ }^{\circ} \mathrm{C}\right)$ for adult emergence. Observations were made on the adult emergence after twenty five days of egg laying. The effect of various exposure periods of cold treatments on larvae of pulse beetle was studied following the same procedure as outlined above, except that the stage of exposure of insects to cold treatments was larval stage (6 days after egg laying). Observations were made on the adult emergence after twenty five days of oviposition.

\section{Results And Discussion}

3.1Effect of sun drying on oviposition of the pulse beetle, Callosobruchus maculatus (Fab.)

The data pertaining to the effect of sun drying on oviposition of pulse beetle, C. maculatus is given in TABLE 1. After one month of exposure to sun for different periods, the number of eggs laid per seed ranged from 0.02 to 0.65 . Highest number of eggs laid per seed was observed in seeds exposed to $4 \mathrm{~h}(0.65)$ duration. Lowest number of eggs per seed was recorded in seeds exposed to $24 \mathrm{~h}(0.02)$ followed by $20 \mathrm{~h}(0.06)$ and $16 \mathrm{~h}$ (0.08) duration. After second, third, and fourth month of exposure 100 per cent of egg mortality of C. maculatus was observed in black gram seeds. Observations recorded on the effect of sun drying on adult emergence of pulse beetle, $C$. maculatus is given in TABLE 2. After one month of exposure to sun for different periods, the number of adult emergence ranged from 2.00 to 10.66. Maximum number of adults were recorded in seeds exposed to $4 \mathrm{~h}$ (10.66) duration. Minimum number of adults were noticed in seeds exposed to $24 \mathrm{~h}$ (2.00) duration which was at par with $20 \mathrm{~h}, 16 \mathrm{~h}$ and $12 \mathrm{~h}$ followed by $8 \mathrm{~h}$ (5.00).During second, third and fourth months of observation 100 per cent adult mortality was recorded. In the present study 100 per cent egg mortality of $C$. maculatus was observed in black gram seeds exposed to sun drying for different hours. There is no significant difference among the exposure periods .This in conformity with the findings of [13] reported that 100 per cent egg mortality of $C$. maculatus when exposed to sunlight for $2 \mathrm{~h}$ in Vigna subterranean (L.). [14] summarised that the infestation of $C$. chinensis during egg stage can be eliminated by exposing the infested seeds to solar radiation for $8 \mathrm{~h}$. This could be due to the fact that eggs are deposited on the surface of the seed comes in direct contact with solar radiation. [15] registered the effect of sun light on the population build-up of Bruchidius atrolineatus (Pic.) and Callosobruchus maculatus (Fab.) This is in conformity with present investigation. [16] studied exposure temperature and time to attain $100 \%$ mortality of insects (Callosobruchus chinensis L.) and eggs in green gram.Time-mortality response of red flour beetle eggs, young larvae, old larvae, pupae and adult stages increased with increase in temperature and exposure time[1.. More specifically, eggs and young larvae are most susceptible at high temperature than old larvae. [18] reported that exposure of $C$. maculatus adults to solar heat at a temperature of $50^{\circ} \mathrm{C}$ for 2, 4, $6 \mathrm{~h}$. decreased the oviposition, retarded egg development and 100 per cent adult mortality in Vigna subterranean. In the present study 100 per cent adult mortality was observed in black gram seeds when exposed to different exposure periods to sun light.These findings are in line with[19] who reported that sun drying of cow pea seeds at bimonthly intervals for 2 days consequently protected the seeds from bruchids attack up to 14 months while the untreated as well as fumigated cowpea seeds were completely destroyed by bruchids after a period of $10^{\text {th }}$ and $12^{\text {th }}$ month respectively. [20] reported that sun drying of seeds for $22 \mathrm{~h}$ destroyed the four stages of both C. maculatus and C. chinensis. [15] reported that with increasing the exposition time to sun light the number of bruchid adults decreased drastically. All the above findings are in agreement with the present investigation. It is evident from the present study that sun drying provided adequate protection of black gram seeds against infestation by $C$. maculatus. It offers a great prospect for successful protection of grain legumes against attack by bruchids for small and medium storage and does not require any extra financial investment.

\subsection{Effect of cold treatment on oviposition of the pulse beetle, Callosobruchus maculatus (Fab.)}

The data related to effect of cold treatment on oviposition of the pulse beetle, C. maculatus is given in TABLE 3.After one month of exposure the number of eggs laid per seed ranged from 0.02 to 0.51 . Maximum 
number of eggs per seed was observed in seeds exposed to $4 \mathrm{~h}(0.51)$ duration. Minimum number of eggs laid per seed was recorded in seeds exposed to $24 \mathrm{~h}(0.02)$ which was at par with $20 \mathrm{~h}(0.08)$.Significant difference was not noticed during the different exposure periods in which 100 per cent mortality was observed in second, third and fourth months of observation.The mean adult emergence after an interval of one, two and three and four months of initial exposure is given in TABLE 4. After one month of exposure the number of adult emergence ranged from 2.66 to 11.33 . Highest number of adults was recorded in seeds exposed to 4h (11.33) duration followed by both $8 \mathrm{~h}$ and $12 \mathrm{~h}$ (10.00) duration. Lowest number of eggs were noticed in seeds exposed to $24 \mathrm{~h}$ (2.66) which was at par with $20 \mathrm{~h}$ (5.33) duration. During subsequent observations, 100 per cent adult mortality was recorded. In the present investigation seeds exposed to $4^{0} \mathrm{C}$ for different exposure periods resulted in 100 per cent mortality. This is in conformity with the reports of earlier workers[21,22,23].The present findings are also in line with[24] who reported that low temperature reduced insect development and killed large number of immature stages of stored grain insects. The insects became inactive and eventually dead at a temperature below $12{ }^{\circ} \mathrm{C}$. [25] revealed that more than 99 per cent of the C. maculatus adults were died when pea seeds were exposed to $-18^{0} \mathrm{C}$ for $6 \mathrm{~h}$. Similar trend was noticed in the present findings where 100 per cent adult mortality of C.maculatus was recorded in all the exposure periods from second month onwards

TABLE 1. Effect of different exposure periods to sun drying on oviposition of the pulse beetle, $C$. maculatus (Fab.)

\begin{tabular}{|c|c|c|c|c|c|}
\hline \multirow{2}{*}{$\begin{array}{c}\text { Exposure Period } \\
(4 \mathbf{h} / \text { day })\end{array}$} & \multicolumn{4}{|c|}{ Number of eggs (Mean of three replications) } & \multirow{2}{*}{$\begin{array}{c}\text { Over all } \\
\text { mean }\end{array}$} \\
\hline & $1^{\text {st }}$ Month & $2^{\text {nd }}$ Month & $3^{\text {rd }}$ Month & $4^{\text {th }}$ Month & \\
\hline 4h (One day) & $\begin{array}{c}0.65 \\
(0.83)^{\mathrm{c}}\end{array}$ & 0.00 & 0.00 & 0.00 & 0.162 \\
\hline 8h (Two days) & $\begin{array}{c}0.14 \\
(0.43)^{\mathrm{b}}\end{array}$ & 0.00 & 0.00 & 0.00 & 0.035 \\
\hline 12h (Three days) & $\begin{array}{c}0.12 \\
(0.41)^{\mathrm{b}}\end{array}$ & 0.00 & 0.00 & 0.00 & 0.03 \\
\hline 16h (Four days) & $\begin{array}{c}0.08 \\
(0.35)^{\mathrm{ab}}\end{array}$ & 0.00 & 0.00 & 0.00 & 0.02 \\
\hline 20h (Five days) & $\begin{array}{c}0.06 \\
(0.33)^{\mathrm{ab}}\end{array}$ & 0.00 & 0.00 & 0.00 & 0.015 \\
\hline 24h (Six days) & $\begin{array}{c}0.02 \\
(0.27)^{\mathrm{a}} \\
\end{array}$ & 0.00 & 0.00 & 0.00 & 0.005 \\
\hline Over all mean & 0.18 & - & - & - & - \\
\hline CD & $0.10^{* * *}$ & - & - & - & \\
\hline CV (\%) & 1.30 & - & - & - & \\
\hline
\end{tabular}

Values in parentheses are square root transformed values

In a column mean followed by a common letter are not significantly different by DMRT $(\mathrm{P}=0.05)$.

**. Significant at $1 \%$ level

TABLE 2. Effect of different exposure periods to sun drying on adult emergence of pulse beetle, C. maculatus (Fab.)

\begin{tabular}{|c|c|c|c|c|c|}
\hline \multirow{2}{*}{$\begin{array}{c}\text { Exposure Period } \\
(\mathbf{4 h} / \text { day) }\end{array}$} & \multicolumn{4}{|c|}{$\begin{array}{c}\text { Number of adults/100g seed } \\
\text { (Mean of three replications) }\end{array}$} & \multirow{2}{*}{ Over all mean } \\
\cline { 2 - 5 } & $\mathbf{1}^{\text {st }}$ Month & $\mathbf{2}^{\text {nd }}$ Month & $\mathbf{3}^{\text {rd }}$ Month & $\mathbf{4}^{\text {th }}$ Month & \\
\hline $4 \mathrm{~h}$ (One day) & $\begin{array}{c}10.66 \\
(3.26)^{\mathrm{c}}\end{array}$ & 0.00 & 0.00 & 0.00 & 2.66 \\
\hline 8h (Two days) & $\begin{array}{c}5.00 \\
(2.23)^{\mathrm{b}}\end{array}$ & 0.00 & 0.00 & 0.00 & 1.25 \\
\hline $12 \mathrm{~h}$ (Three days) & $\begin{array}{c}2.33 \\
(1.48)^{\mathrm{a}}\end{array}$ & 0.00 & 0.00 & 0.00 & 0.58 \\
\hline 16h (Four days) & $\begin{array}{c}2.33 \\
(1.48)^{\mathrm{a}}\end{array}$ & 0.00 & 0.00 & 0.00 & 0.58 \\
\hline 20h (Five days) & $\begin{array}{c}2.33 \\
(1.48)^{\mathrm{a}}\end{array}$ & 0.00 & 0.00 & 0.00 & 0.58 \\
\hline 24h (Six days) & 2.00 & 0.00 & 0.00 & 0.00 & 0.50 \\
\hline
\end{tabular}


Effect of hot and cold treatments for the management of Pulse beetle Callosobruchus maculatus

\begin{tabular}{|l|c|c|c|c|c|}
\hline & $(1.40)^{\mathrm{a}}$ & & & & \\
\cline { 1 - 5 } Over all mean & 4.11 & - & - & - & \multirow{2}{*}{-} \\
\cline { 1 - 5 } CD & $0.63^{* *}$ & - & - & - & \\
\cline { 1 - 5 } & 5.30 & - & - & - & \\
\hline
\end{tabular}

Values in parentheses are square root transformed values

In a column mean followed by a common letter are not significantly different by DMRT ( $\mathrm{P}=0.05)$.

**-Significant at $1 \%$ level

TABLE 3. Effect of cold treatment on oviposition of the pulse beetle, C. maculatus (Fab.)

\begin{tabular}{|c|c|c|c|c|c|}
\hline \multirow{2}{*}{$\begin{array}{l}\text { Exposure Period } \\
\left(4^{0} \mathrm{C}\right)\end{array}$} & \multicolumn{4}{|c|}{ Number of eggs (Mean of three replications) } & \multirow{2}{*}{$\begin{array}{c}\text { Over all } \\
\text { mean }\end{array}$} \\
\hline & $1^{\text {st }}$ Month & $2^{\text {nd }}$ Month & $3^{\text {rd }}$ Month & $4^{\text {th }}$ Month & \\
\hline $4 \mathrm{~h}$ & $\begin{array}{c}0.51 \\
(0.74)^{\mathrm{c}}\end{array}$ & 0.00 & 0.00 & 0.00 & 0.12 \\
\hline $8 \mathrm{~h}$ & $\begin{array}{c}0.17 \\
(0.46)^{\mathrm{b}}\end{array}$ & 0.00 & 0.00 & 0.00 & 0.04 \\
\hline $12 \mathrm{~h}$ & $\begin{array}{c}0.16 \\
(0.46)^{b}\end{array}$ & 0.00 & 0.00 & 0.00 & 0.04 \\
\hline $16 \mathrm{~h}$ & $\begin{array}{c}0.14 \\
(0.43)^{\mathrm{b}}\end{array}$ & 0.00 & 0.00 & 0.00 & 0.03 \\
\hline $20 \mathrm{~h}$ & $\begin{array}{c}0.08 \\
(0.36)^{\mathrm{ab}}\end{array}$ & 0.00 & 0.00 & 0.00 & 0.02 \\
\hline $24 \mathrm{~h}$ & $\begin{array}{c}0.02 \\
(0.26)^{\mathrm{a}}\end{array}$ & 0.00 & 0.00 & 0.00 & 0.005 \\
\hline Over all mean & 0.18 & - & - & - & \\
\hline CD & $0.10 * *$ & - & - & - & - \\
\hline CV (\%) & 7.27 & - & - & - & \\
\hline
\end{tabular}

Values in parentheses are square root transformed values

In a column mean followed by a common letter are not significantly different by DMRT $(\mathrm{P}=0.05)$.

**-Significant at $1 \%$ level

TABLE 4. Effect of cold treatment on adult emergence of pulse beetle, $C$. maculatus (Fab.)

\begin{tabular}{|c|c|c|c|c|c|}
\hline \multirow{2}{*}{ Exposure period $\left(4^{0} \mathrm{C}\right)$} & \multicolumn{4}{|c|}{$\begin{array}{l}\text { Number of adults/100g seed } \\
\text { (Mean of three replications) }\end{array}$} & \multirow{2}{*}{$\begin{array}{c}\text { Over all } \\
\text { mean }\end{array}$} \\
\hline & $1^{\text {st }}$ Month & $2^{\text {nd }}$ Month & $3^{\text {rd }}$ Month & $4^{\text {th }}$ Month & \\
\hline $4 \mathrm{~h}$ & $\begin{array}{c}11.33 \\
(3.36)^{d}\end{array}$ & 0.00 & 0.00 & 0.00 & 2.82 \\
\hline $8 \mathrm{~h}$ & $\begin{array}{l}10.00 \\
(3.16)^{\mathrm{cd}}\end{array}$ & 0.00 & 0.00 & 0.00 & 2.50 \\
\hline $12 \mathrm{~h}$ & $\begin{array}{l}10.00 \\
(3.16)^{\mathrm{cd}}\end{array}$ & $\overline{0.00}$ & 0.00 & 0.00 & 2.50 \\
\hline $16 \mathrm{~h}$ & $\begin{array}{l}6.66 \\
(2.55)^{\mathrm{bc}}\end{array}$ & 0.00 & 0.00 & 0.00 & 1.66 \\
\hline $20 \mathrm{~h}$ & $\begin{array}{c}5.33 \\
(2.25)^{\mathrm{ab}}\end{array}$ & 0.00 & 0.00 & 0.00 & 1.33 \\
\hline $24 \mathrm{~h}$ & $\begin{array}{c}2.66 \\
(1.59)^{\mathrm{a}}\end{array}$ & 0.00 & 0.00 & 0.00 & 0.66 \\
\hline Over all mean & 7.66 & - & - & - & - \\
\hline CD & $0.74 * *$ & - & - & - & \\
\hline $\mathrm{CV}(\%)$ & 4.37 & - & - & - & \\
\hline
\end{tabular}

Values in parentheses are square root transformed values

In a column mean followed by a common letter are not significantly different by DMRT $(\mathrm{P}=0.05)$.

**- Significant at $1 \%$ level 


\section{Conclusion}

Bruchids Callosobruchus maculatus (Fab) are the most common and widespread insect pests during storage in pulses. Pods should be harvested as soon as they mature and the seeds are sun dried or stored in refrigerated conditions in an air tight beetle-proof containers. This way of physical control will ensure that the quality of the grain entering the storage facility does not deteriorate over time. These measures are eco friendly ,environmentally safe and cost effective too.

\section{References}

[1] Das, M. Biswas and K. K. Ghosh. Genetic divergence in green gram (Vigna radiata L.). Journal of Agronomy. 9(3),2010,126-130.

[2] FAO. http://faostat.fao.org/default.aspx, accessed December 2010 to March2011.

[3] Anonymous. Post-harvest food losses in Developing Countries. National. Academy of Science, Washington, D. C.,1978, p. 220.

[4] A.B.Saxena, Recent advances in Entomology. Anmol publications Pvt. Ltd.New Delhi-11, 1995,pp. 334-335.

[5] D.KSalunkhe, S. S. Kadam and J. K. Chavan. Post-harvest biotechnology of food legumes. CRC Press, Boca Raton, FL,1985, p. 160 .

[6] O.Ogunwolu, and O. Idowu. Potential of powderd Zanthoxylum zanthoxyloides root bark and Azadirachta Indica seed for control of the cowpea seed bruchid, Callosobruchus maculatus (Fab.) in Nigeria. Journal of African Zoology, 108(8),1994,521-528

[7] F.A.Ajayi and N. E. S. Lale,. Seed coat texture, host species and time of application affect and the efficacy of essential oils applied for the control of Callosobruchus maculatus (Fab.) in stored pulses. International Journal of Pest Management, 47(3),2001,161166.

[8] L.A.Tapondjou, C. Alder, H. Bouda and D. A. Fontem. .Efficacy of powder and essential oil from Chenopodium ambrosioides leaves as post- harvest grain protectants against six stored product beetles. Journal of Stored Product Research, 38(4),2002,395402.

[9] F.A.Talukder, and P. E. Howse. Repellent, toxic and food protectant effects of Aphanamixis polystachya extracts against the pulse beetle, Callosobruchus chinensis (L.) in storage. Journal of Chemical Ecology, 20(4),1994, 498-504.

[10] E.U.Okonkwo, and W. I. Okoye.. The efficacy of four seed powders and essential oils as protectants of cowpea against infestation by Callosobruchus maculatus (Fab.) in Nigeria. International Journal of Pest Management, 42(3),1996,143-146.

[11] C.Park, , S. I. Kim and Y. J. Ahn., Insecticidal activity of Acorus gramineus rhizome against three coleopteran stored product insects. Journal of Stored Product Research, 39(3),2003, 333-342.

[12] C.Somta, , P. Somta, N. Tomooka, P. A. C. Ooi, D. A. Vaughan and P. Srinivas Characterization of new sources of mung bean (Vigna radiata L.) resistance to bruchids, Callosobruchus spp. (Coleoptera: Bruchidae). Journal of Stored Product Research, 44,2008, 316-321.

[13] N.E.S.Lale, and S. Vidal. Mortality of different development stages of Callosobruchus maculatus (Fab.) and Callosobruchus subinnotatus (Pic.) in stored bambara ground nut exposed to simulated solar heat. Journal of Stored Product Research, 107(5),2000, 553-559.

[14] Swaroop singh and Gireesh sharma.. Pulse beetle management through solar energy in stored green gram seeds. Seed Research, 31(1),2003. 84-89.

[15] A.Doumma, Effects of sun exposition on population of bruchids in cowpea (Vigna unguiculata (L.)) storage system in Niger. Pest Management of Horticultural Ecosystems, 12(1),2006, 5-7

[16] K.K,Singh. N. Kotwaliwale and R. Singh.. Effect of temperature and time on thermal disinfestation of green gram.Journal of Agricultural Engineering, 46(2),2009 14-17.

[17] D.Boina and B. Subramanyam, Relative susceptibility of Tribolium confusum life stages expose to elevated temperatures. Journal of Economic Entomology, 97(6):,2004,2168-2173.

[18] N.E.S.Lale, and S. Vidal. Simulation studies on the effects of solar heat on egg laying, development and survival of Callosobruchus maculatus (Fab.) and Callosobruchus subinnotatus (Pic.) in stored bambara ground nut. Journal of Stored Product Research., 39(5):,2003,447-458.

[19] P.Srimathi, and K. R. Ramaswamy. Effect of fumigation and sun drying on the storability of cow pea seeds. Papers presented at National Seminar on Research Perspectives on Seed Storage. Tamil Nadu Agricultural University, Coimbatore April 7 and 8, 1983.

[20] M.M.Rahman, Control measures for important insect pests of major pulses, Bangladesh Agricultural Research Institute, Joydebpur, Bangladesh.1991.

[21] F.L.Watters,. The effects of short exposures to sub-threshold temperatures on subsequent hatching and development of eggs of Tribolium confusum (Coleoptera:Tenebrionidae).Journal of Stored Product Research., 2, 1966,,81-90.

[22] J.Daumal, P. Jourdheuil and R. Tomassone.. Low temperature effects on embryonic development of Indian-meal moth. Transactions of the American Society of Agricultural Engineers, 27,1974, 1579-1585.

[23] J.A.Johnson, and P. L. Wofford. Effects of age on response of eggs of Indian meal moth and navel orange worm (Lepidoptera: Pyralidae) to subfreezing temperatures. Journal of Economic Entomology, 84,1991, 202-205.

[24] R.K.Upadhyay, and S. Ahmad. Management strategies for control of stored grain insect pests in farmer stores and public ware houses. World Journal of Agricultural Science, 7(5),2011, 527-549.

[25] A.Judy, and A. Karen. Control of cowpea weevil, Callosobruchus maculatus (F.) using freezing temperatures. Horticultural Crops Research. USDA-ARS.2006. 